
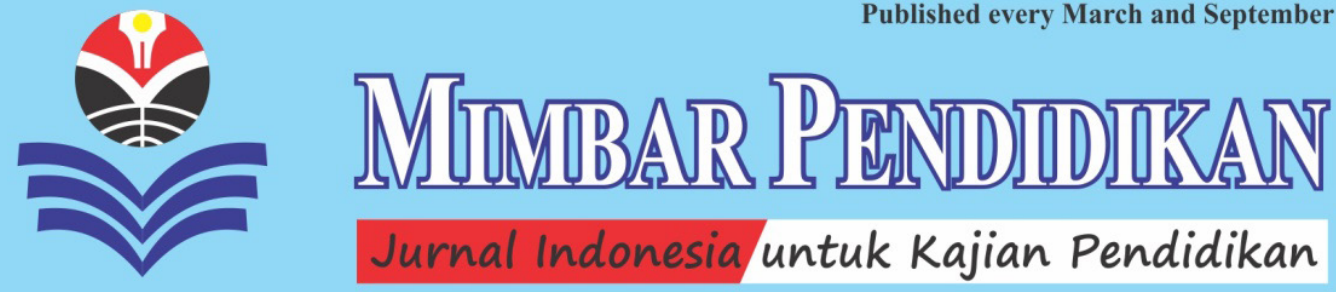

\title{
Conflict Management among Selected Officials of State Universities and Colleges in the Philippines
}

\begin{abstract}
The study concerns on dominant conflict management approach of officials of selected SUCs (State Universities and Colleges) in the Philippines. Related studies and literature on the importance of systems approach in organizational analysis along with theories and practices on the role of culture in conflict analysis and resolution along with the principles and theories in negotiation and conflict management system design are presented and utilized as the research theoretical framework. Kenneth W. Thomas \& Ralph H. Kilmann (2017)'s conflict behavior survey instrument was also used. The results show that the dominant conflict management style of officials from the selected SUCs in the Philippines is that of "collaborator". The respondents open to other conflict management styles in responding to conflicts, including compromiser, accommodator, controller, and avoider. While the sex and administrative positions of the respondents (university officials) do not have any statistical significant difference in their preference of conflict management styles. So, more than majority of the respondents are using several conflict management styles as they address interpersonal conflicts in various contexts.

KEY WORD: Conflict Management Style; University Officials; Interpersonal Conflicts.
\end{abstract}

ABSTRAKSI: "Manajemen Konflik diantara para Pejabat Terpilih pada Universitas dan Perguruan Tinggi Negeri di Filipina". Studi ini mengenai pendekatan manajemen konflik yang dominan dari para pejabat SUCs (Universitas dan Perguruan Tinggi Negeri) tertentu di Filipina. Terkait dengan studi dan literatur tentang pentingnya pendekatan sistem dalam analisis organisasi bersama dengan teori dan praksis tentang peran budaya dalam analisis dan resolusi konflik bersama dengan prinsip-prinsip dan teori dalam negosiasi dan desain sistem manajemen konflik disajikan dan digunakan sebagai kerangka teori penelitian. Instrumen survei perilaku konflik dari Kenneth W. Thomas \& Ralph H. Kilmann (2017) juga digunakan. Hasil kajian menunjukan bahwa gaya manajemen konflik dari pejabat yang dominan dalam SUC terpilih di Filipina adalah "kolaborator". Responden terbuka terhadap gaya manajemen konflik lainnya dalam menanggapi konflik, termasuk kompromi, akomodator, pengontrol, dan penghindar. Manakala jenis kelamin dan posisi administratif responden (pejabat universitas) tidak memiliki perbedaan statistik yang signifikan dalam preferensi mereka terhadap gaya manajemen konflik. Jadi, lebih dari mayoritas responden menggunakan beberapa gaya manajemen konflik ketika mereka menangani konflik interpersonal dalam berbagai konteks.

KATA KUNCI: Gaya Manajemen Konflik; Pejabat Universitas; Konflik Antarpribadi.

About the Authors: Ronald Allan S. Mabunga, Ph.D. is a Director, Center for Planning \& Quality Assurance PNU (Philippine Normal University), Taft Avenue, Manila 1000, the Philippines. Maria Eljie M. Mabunga, M.A. is a Professor in Peace Education at the PNU, Taft Avenue, Manila 1000, the Philippines. For academic interests, the authors are able to be contacted via e-mails address at: mabunga.ras@pnu.edu.ph and mabunga@gmail.com

Suggested Citation: Mabunga, Ronald Allan S. \& Maria Eljie M. Mabunga. (2019). "Conflict Management among Selected Officials of State Universities and Colleges in the Philippines" in MIMBAR PENDIDIKAN: Jurnal Indonesia untuk Kajian Pendidikan, Volume 4(1), Maret, pp.1-20. Bandung, Indonesia: UPI [Indonesia University of Education] Press, ISSN $2527-$ 3868 (print) and 2503-457X (online).

Article Timeline: Accepted (October 28, 2018); Revised (December 27, 2018); and Published (March 30, 2019). 


\section{INTRODUCTION}

Public HEIs (Higher Education

Institutions) play an important role in achieving societal goals set by the current political administration of the Philippines. Under the 2011-2016 MTPDP (Medium Term Philippine Development Plan) of President Benigno C. Aquino III, one of the KRA (Key Result Areas) focuses on "poverty reduction and empowerment of the poor and vulnerable". It is within this KRA that public institutions of higher learning are expected to have their contributions through education (NEDA, 2014; and Anderson \& Hipgrave, 2015).

In view of the foregoing role of public HEIs, the SUCs (State Universities and Colleges), in particular, have been implementing PAP (Programs, Activities, and Programs) based on their respective mandate, i.e. based on their charter or law that created them. In the implementation of such programs, the role of the administrators becomes of critical and significant importance to achieve whatever goals and objectives have been organized (Haddad, 1995; Lorena \& Torio, 2017; and Santiago III, 2018).

As the road to success will never be an easy journey in consideration of a number of factors that may contribute to the success and/or failure of such academic organization. One of these factors could be the potential conflict that may occur between and among the various stakeholders in the academic community. Conflict, in this context, is seen as an expressed struggle, in which two or more interdependent parties may experience strong emotion from a perceived difference in needs, values, perceptions, or positions (Putnam \& Poole, 1987; Katz \& Lawyer, 1992; Hartwick \& Barki, 2002; De Janasz, Dowd \& Schneider, 2006; Kinicki \& Kreitner, 2008; and Thakore, 2013).

Moreover, the academe, as an organization, is vulnerable to such conflict.
In particular, conflicts in the academe may occur when its various stakeholders engage in activities that are perceived to have incompatibilities and differences vis-à-vis their respective needs, values, and/or positions (Roloff, 1987; Jarboe \& Witteman, 1996; Jannat, 2007; and Durban \& Catalan, 2012).

It is within this context that conflict management may come into the picture in the overall management and operation of the administrators' respective functions in an academic setting. Conflict is an all-pervasive element in every society. Although conflicts may end up in destruction and even death, conflicts may also result in increased effectiveness and efficiency, enhanced relationships, and advance goal attainment (Katz \& Lawyer, 1992; and Jeong, 2008). Hence, conflict management is argued to be a critical element as it pertains to the processes of resolving and minimizing disagreements that may have resulted from the perceived or real differences between and among the stakeholders in an academic institution (Greenhalgh, 1996; and De Dreu \& Gelfand, 2008).

According to the CHED (Commission on Higher Education), there are more than 2,000 HEIs in the Philippines (CHED, 2015). Of this number, around $15 \%$ are state universities and colleges, including local community universities and colleges; and the remaining $85 \%$ are private higher education institutions. More specifically, there are 113 state universities and colleges across the country, excluding the satellite campuses (CHED, 2015; Orbeta Jr., Gonzales \& Cortes, 2016; and Malolos \& Tullao, Jr., 2018).

In view of the foregoing, a study examining the conflict management style of some officials or administrators of SUCs was conducted to determine how they responded and resolved conflicts that they may have encountered in the performance of their respective functions. The results may be used as the basis for future development 
of a conflict management system designed for school settings. The theory of systems approach in organizational analysis along with perspectives on high and low context cultures; and a comparative analysis of different conflict management system designs relevant to negotiation are discussed and analyzed (Bush \& Folger, 2005; De Dreu \& Gelfand, 2008; Mabunga \& Mabunga, 2014; and Malolos \& Tullao, Jr., 2018).

In particular, this study seeks to answer the following questions: (1) What is the dominant conflict management style of some university officials from selected SUCs?; and (2) What other conflict management styles are university officials open to using in addressing interpersonal conflicts other than the dominant one?

The first question aims to provide a research-based data regarding the conflict management style of selected university officials $v i s-\grave{a}$-vis the various alternative dispute resolution systems. The second question focuses on the factors that need to be considered by SUCs in developing its conflict management system design.

Review of Related Literature. No organization is immune to conflicts - be it in the government, community, church, business, and even in the academe. An important approach to better understand an organization is to examine the main assumptions underlying the perspective of organizations as systems. According to D. Silverman (1971), and other scholars, a proponent of systems theory as an approach in organizational analysis, organizations are composed of a set of interdependent parts (Silverman, 1971; Millett, 1998; and Chikere \& Nwoka, 2015).

Every part of an organization contributes and receives something from the whole (Silverman, 1971:27; and Denhardt \& Catlaw, 2015). For instance, an academic organization such as a university is composed of academic and non-academic offices, colleges or departments that are interrelated or interdependent. These interdependent parts are generally working toward a common vision, mission, and goal for their organization. Furthermore, organizations have needs for survival that is, as social systems, organizations are governed by a series of needs which they must satisfy if the organizations are to survive (Silverman, 1971; Langlois, 1982; Luhmann, 1995; Lang, 2009; and Scott \& Davis, 2016).

Hence, as a system, an organization is expected to examine to which it utilizes its available resources for optimum needsatisfaction. Using the example earlier, any university would have its own set of needs - needs that to be satisfied will depend on the manner it maximizes the use of all the available resources, both human and nonhuman. These university needs are not only related to the basic functions of a university (instruction, research, production, and extension), but also to the social-politicaleconomic needs of all the members of the academic community. Finally, it was argued that if organizations have needs, then, they are also taking action to satisfy those needs (Silverman, 1971; Langlois, 1982; Luhmann, 1995; and Wealleans, 2017).

Logically, organizations are, therefore, responsible for its behavior and actions in their objective to address their needs. Applied within the context of a university, members of the academic community are responsible for their behavior and actions in meeting their needs (Sparks, 2007; and Wealleans, 2017).

It is important that an organization is examined and analyzed as a system in consideration of the underlying assumptions presented in the foregoing. From a standpoint of an organization as a system, the next section provides a perspective of looking into the importance of examining, whether the organization is characterized by a high context culture or a low context culture (Geertz, 1993; and Browaeys \& Price, 2015). 
On the High Context Culture and Low Context Culture. High context cultures are characterized by being relational, collectivist, intuitive, and contemplative where people have high regards on interpersonal relationships (Hall, 1976; Avruch, 1998; and Goehre, 2016). Developing trust among the members of the culture is of paramount importance and the people generally prefer group harmony and consensus rather than individual achievement (Hall, 1976; and Browaeys \& Price, 2015).

People in high context cultures also emphasize the "We-identity" than the "I-identity" (Avruch, 1998; and Proszowska, 2015). In terms of communication, words are considered not as important as context, i.e. the speaker's tone of voice, facial expression, body language, gestures, or postures. In addition, communication tends to be more indirect and more formal along with the use of flowery language, humility, and elaborate apologies (Hall, 1976; Avruch, 1998; and Irwin, 2001).

Low context cultures, on the other hand, are typically characterized by being logical, linear, individualistic, and action-oriented where people usually value logic, facts, and directness (Hall, 1976; Avruch, 1998; and Wurtz, 2006). Solving problems based on presenting and evaluating empirical data is important in decision making, which eventually leads to actions. In terms of identity, the emphasis of the people in low context cultures is on the "I-identity" and not the "We-identity" (Avruch, 1998; and Proszowska, 2015).

As far as communication is concerned, people in the low context cultures are typically straightforward, concise, and efficient in expressing what actions are expected. In the same vein, communicators in low context cultures usually strive of using precise words and intend them to be taken as literal as possible (Hall, 1976; Avruch, 1998; and Illes, 2001).
In the Philippines, F.L. Jocano (1999), and other scholars, argued that Filipinos value culture so much in organizational management. They posit that the family constitutes the core unit of the Filipino social system and the central concern of every Filipino is the welfare of the family since it is the only secure place in this fragile world of social realities (Toh \& Cawagas, 1987; Cooper et al., 1993; Jocano, 1999; and Becker, 2003). F.L. Jocano (1999), and other scholars, further suggested that the family is the source of economic, social, and psychological supports for all its members. Hence, it can be inferred that such Filipino culture valuing the family has implicit and explicit implication to organizational management (Constantino, 1994; Jocano, 1999; Spencer-Oatey, 2012; and Morillo, Capuno \& Mendoza, Jr., 2013).

Studies by J.M. Brett (1984); K. Fouseki (2009); H.M. Gutmann (2009); J. Galace \& L. Castro (2010); K. Spaho (2013); and R.A.S. Mabunga \& M.E.M. Mabunga (2014), all pointed to the importance of conflict management system design. More particularly, the foregoing authors argued that organizational conflicts may have both positive and negative implications to an organization depending on how such conflicts are addressed and/or managed (Brett, 1984; Fouseki, 2009; Gutmann, 2009; Galace \& Castro, 2010; Spaho, 2013; and Mabunga \& Mabunga, 2014).

From a holistic standpoint, however, it can be argued that in reality, it would be too simplistic to use the dichotomy of high and low context culture in describing organizational cultures. Put succinctly, any culture may have the characteristics of both cultural contexts with a pre-dominance of one context over the other. As such, the negotiation approach to be employed in any cultural context should take into consideration the possible interplay and presence of the dynamics of both the high context and low context cultures (Toh \& 
Table 1:

Comparative Presentation of Dispute System Design

\begin{tabular}{|c|c|c|c|c|c|}
\hline & $\begin{array}{l}\text { W.L. Ury, J.M. } \\
\text { Brett \& S. } \\
\text { Goldberg (1993) }\end{array}$ & $\begin{array}{l}\text { J. Hall (1976); and } \\
\text { C. Costantino \& M. } \\
\text { Merchant (1996) }\end{array}$ & $\begin{array}{l}\text { M. Rowe } \\
\text { (1997) }\end{array}$ & $\begin{array}{l}\text { K. Slaikeu \& R. } \\
\text { Hasson (2001) }\end{array}$ & J. Lynch (1998) \\
\hline $\begin{array}{l}\text { Types of } \\
\text { process }\end{array}$ & $\begin{array}{l}\text { Power-based, } \\
\text { rights-based, and } \\
\text { interests-based } \\
\text { processes. }\end{array}$ & $\begin{array}{l}\text { Power-based, rights- } \\
\text { based, and interests- } \\
\text { based processes giving } \\
\text { more emphasis on } \\
\text { the most appropriate } \\
\text { process depending } \\
\text { on the nature of the } \\
\text { dispute. }\end{array}$ & $\begin{array}{l}\text { Power- } \\
\text { based and } \\
\text { interests-based } \\
\text { processes } \\
\text { with emphasis } \\
\text { on conflict } \\
\text { prevention. }\end{array}$ & $\begin{array}{l}\text { Power-based, } \\
\text { rights-based, } \\
\text { interests-based, } \\
\text { and avoidance } \\
\text { as means of } \\
\text { addressing } \\
\text { conflict. It has } \\
\text { an emphasis } \\
\text { on conflict } \\
\text { prevention. }\end{array}$ & $\begin{array}{l}\text { Interests-based } \\
\text { and rights- } \\
\text { based as the } \\
\text { initial processes } \\
\text { in addressing } \\
\text { dispute. Power- } \\
\text { based process is } \\
\text { seen as necessary } \\
\text { in certain } \\
\text { disputes. Focuses } \\
\text { on conflict } \\
\text { prevention. }\end{array}$ \\
\hline
\end{tabular}

Cawagas, 1987; Constantino, 1994; and Pauwels, 2012).

From the foregoing analysis, the next part of this paper shall dwell on a brief discussion about negotiation and an analysis of different dispute system designs. The analysis of the various dispute system designs is based on the comparison of conflict management models.

\section{On the Negotiation for Conflict}

Management. Negotiation has been defined as a social process, in which two or more parties interact in the search for an acceptable position with regard to their differences and concerning the same issue of conflict (Breslin \& Rubin eds., 1993; Raiffa, 2002; HBES, 2003; Lewicki, Barry \& Saunders, 2007; Pfetch, 2007; and Germann, 2012). In general, negotiation can be distributive or integrative. Distributive negotiation is considered as a zero-sum or win-lose type of negotiation, where the gain by one side is the loss or at the expense of the other side. Integrative negotiation, on the other hand, is perceived as a win-win or collaborative type of negotiation, where the parties usually cooperate to achieve maximum benefits by integrating interests into an agreement (HBES, 2003; Lewicki, Barry \& Saunders, 2007; and Alfredson \&
Cungu, 2008).

More often than not, the foregoing types of negotiation are intertwined with the basic strategies that can be used in negotiation to wit: accommodating (lose to win); avoiding (lose-lose); competitive (win-lose); collaborative (win-win); and compromise (split the difference). Each strategy, generally, applies to a particular context and has its corresponding strengths and weaknesses; hence, none of these strategies can be considered as the best way of addressing any dispute through the process of negotiation (Lewicki, Barry \& Saunders, 2007; and Pfetch, 2007).

Another way of addressing disputes through the process of negotiation is by exploring the nature of the processes used in the conflict resolution, that is whether any of the following is significantly applied: powerbased approach, rights-based approach, and interest-based approach. Table 1 provides various perspectives of conflict management system designs from: J. Hall (1976); W.L. Ury, J.M. Brett \& S. Goldberg (1993); C. Costantino \& C. Merchant (1996); M. Rowe (1997); J. Lynch (1998); and K. Slaikeu \& R. Hasson (2001).

Table 1 identified several conflict management system designs. What seems 
to be common among the above mentioned designs is the use of three main processes of negotiation, namely: the power-based, the rights-based, and the interests-based dispute systems (Ury, Brett \& Goldberg, 1993; Costantino \& Merchant, 1996; and Lewicki, Barry \& Saunders, 2007). The power-based dispute system is generally characterized by the use of extreme and sometimes violent measures, such as violent rallies and demonstrations, and other similar violent activities as means of resolving the dispute. Power-based system is a process in which someone is coerced to do something she or he would otherwise not do. It is worth noting the fact that all dispute systems identified in table 1 suggest the use of a power-based process as a means of last resort in addressing a dispute.

The rights-based system is a process in which a third party imposes a decision on disputants on the basis of their rights as defined by laws, contracts, rules, or regulations (Ury, Brett \& Goldberg, 1993; Costantino \& Merchant, 1996; and Noussia, 2010). Litigations and grievance processes are considered as typical examples of rightsbased system used in resolving a conflict. All conflict management models above have indicated that the rights-based process can be used as a means of addressing a dispute although it is not considered as the primary approach (Conbere, 2001; and Fisher, 2010).

It is important to note, however, that the use of interests-based dispute system as the primary means of addressing a dispute is common among the models identified above. Interests-based system is a process in which parties retain control of and develop their own solutions. Generally, interestsbased dispute system constitutes the use of facilitation and mediation as approaches in resolving a dispute (Ury, Brett \& Goldberg, 1993; Costantino \& Merchant, 1996; and Winslade \& Monk, 2001).

In general, it can be inferred from the preceding presentation that there are certain factors to consider in designing a conflict management system for any organization. These factors include the perspective of using the systems approach in organizational analysis; the high context and low context cultures; and the whole gamut of negotiation processes relevant to conflict management system designs to choose from. Choosing the appropriate conflict management system is, therefore, the main challenge on the part of any organization (Rahim, 2001; Schwarz, 2002; and Overton \& Lowry, 2013).

However, as can be inferred from the dispute system designs presented above, a pro-active conflict management model should always clarify issues, interests, and be able to foster creativity and help to develop a more constructive and harmonious working relationships (SPIDR, 1999; De Dreu \& Gelfand, 2008; and Mabunga \& Mabunga, 2014). Conflict management system design should provide an innovative and effective avenue for an organization and its employees to develop the necessary tools and skills to realize their goals, which may involve substantial gains in productivity, cost savings, and interpersonal and workplace morale - as shown in the framework of figure 1.

The illustration in the figure 1 highlights three negotiation approaches - interestsbased system, rights-based system, and power-based system. The above conflict management system model is based on the six principles proposed by W.L. Ury, J.M. Brett \& S. Goldberg (1993); and C. Costantino \& C. Merchant (1996). These six practical principles, are: (1) putting the focus on interests and not on positions; (2) providing loop-backs or making procedures available that allow the parties to return to a lower-cost method such as mediation; (3) providing low-cost rights and power backups - offering low-cost alternative, such as arbitration if interest-based procedures fail; (4) preventing unnecessary conflict and heading off future disputes through a 


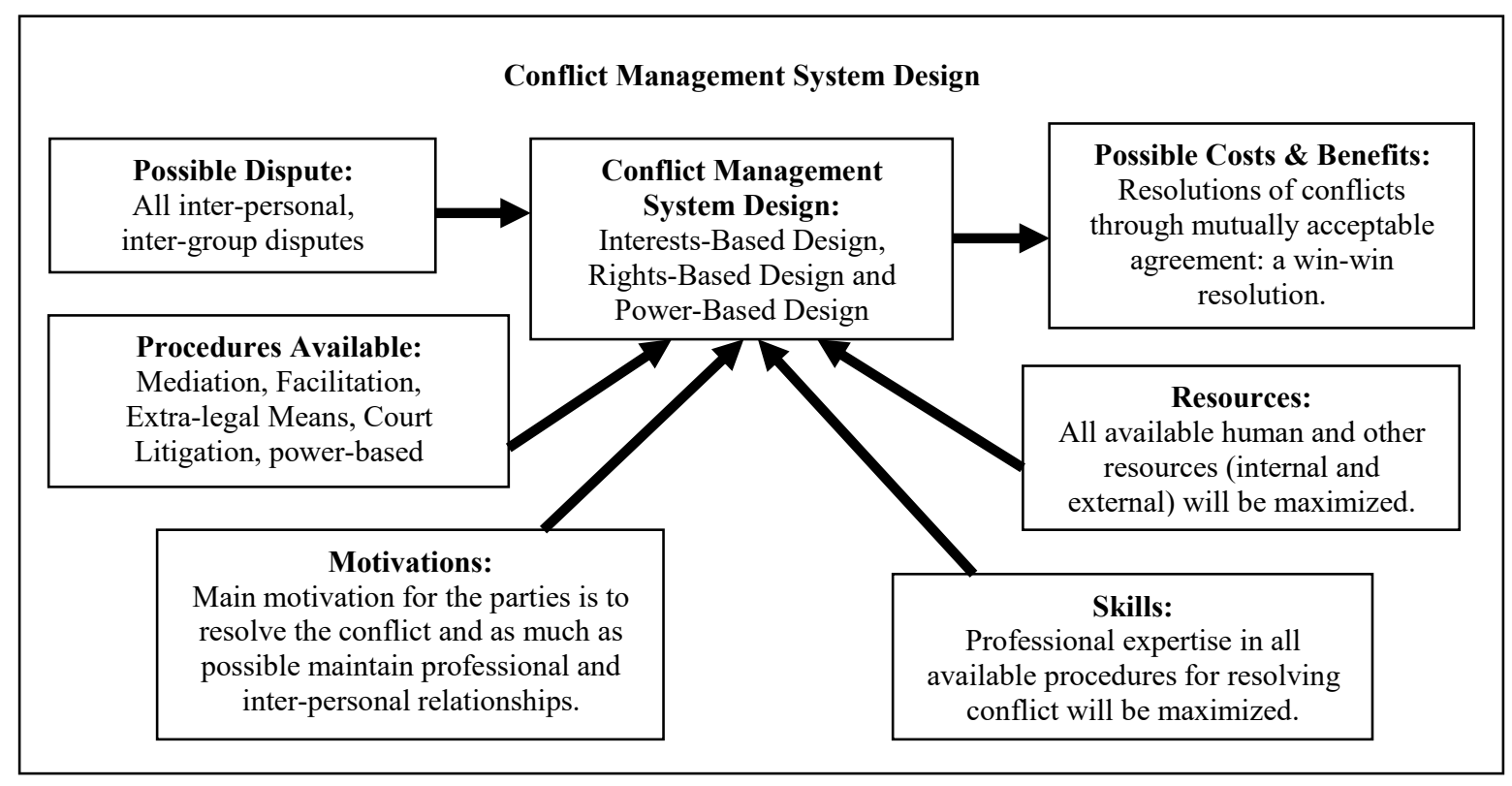

Figure 1:

Conflict Management System Model

(Source: W.L. Ury, J.M. Brett \& S. Goldberg, 1993; and C. Costantino \& C. Merchant, 1996)

built-in consultation before and after the dispute resolution; (5) arranging the dispute system design procedures from low-to-high cost sequence - encouraging interestsbased before the rights-based design; and (6) providing the motivation, skills, and resources necessary ensuring that any of the dispute system design procedures are supported and used (Ury, Brett \& Goldberg, 1993; and Costantino \& Merchant, 1996).

By following the foregoing principles, it can be inferred that HEIs (Higher Education Institutions) may use the above mentioned dispute systems according to the following priorities - using interests-based processes first followed by the rights-based processes and finally the power-based processes, if necessary ( $c f$ De Dreu \& Gelfand, 2008; Mabunga \& Mabunga, 2014; dan Gebregiorgs, 2018).

Finally, J. Blake \& S. Mouton (1970); J. Hall (1976); W.R. Pace (1983); J.G. Cragan \& D.W. Wright (1986); and S. Yirik, B.I. Yildirim \& N. Cetinkaya (2015) provided another perspective in conflict resolution by determining the conflict management styles of the disputing parties. In particular, they presented five possible styles in managing conflict to wit: controller or power-based; compromiser or interest-based and rightsbased; collaborator or interest-based; accommodator or interest-based; and avoider or interest-based and rights-based (Blake \& Mouton, 1970; Hall, 1976; Pace, 1983; Cragan \& Wright, 1986; and Yirik, Yildirim \& Cetinkaya, 2015).

A controller is both assertive and uncooperative - an individual pursues his or her own concerns at the other person's expense. A compromiser is intermediate in both assertiveness and cooperativeness. The object is to find some expedient, mutually acceptable solution that partially satisfies both parties. A collaborator is both assertive and cooperative. Collaborating involves an attempt to work with the other person to find some solution that fully satisfies the concerns of both persons. An accommodator is unassertive and cooperative - the opposite of competing. When accommodating, an individual neglects his or her own concerns to satisfy the concerns of the other person; 
there is an element of self-sacrifice in this mode. Lastly, an avoider is unassertive and uncooperative - the individual does not immediately pursue his own concerns or those of the other person (Conbere, 2001; Mabunga \& Mabunga, 2014; and Yirik, Yildirim \& Cetinkaya, 2015).

\section{METHODS}

This study employed a quantitative research method. In particular, frequency distributions and percentages are used in its data interpretation and analysis. Purposive sampling is used to select the research respondents, who answered an international standard questionnaire on conflict behavior survey developed by Ralph H. Kilmann \& Kenneth W. Thomas (1974) and Kenneth W. Thomas \& Ralph H. Kilmann (2017) entitled Conflict Mode Instrument (Kilmann \& Thomas, 1974; and Thomas \& Kilmann, 2017).

Research Design. The research is anchored on the various literature in conflict management system design, systems approach in organizational analysis, culture and conflict and negotiation, with particular emphasis on ADR or Alternative Dispute Resolutions (Lewins, 2001; Stipanowich \& Lamare, 2012; Coates, Furlong \& Downie, 2013; and Mabunga \& Mabunga, 2014). In the same vein, it uses the survey instrument developed by Ralph H. Kilmann \& Kenneth W. Thomas (1974); Kenneth W. Thomas \& Ralph H. Kilmann (2017); and other scholars, which is designed to assist individuals in becoming aware of their characteristic approach or style in managing interpersonal, group and inter-group conflicts (Kilmann \& Thomas, 1974; Rahim, 2001; Druckman, 2005; Omisore \& Abiodun, 2014; and Thomas \& Kilmann, 2017).

Research Participants/Respondents. Participants in this research include 102 officials from at least 2 SUCs (State Universities and Colleges) representing the 17 political administrative regions in the
Philippines. Purposive sampling method was used to identify the state universities and colleges to be selected for this research. Two universities and/or colleges were chosen to represent each of the 17 administrative regions in the country. Three randomly selected officials in each of the universities were then selected bringing the total number of respondents to 102 . These officials include College Deans, Associate Deans and/or Directors of Academic, and Administrative Offices or Centers (Denzin \& Lincoln, 2003; Marshall \& Rossman, 2006; and Mabunga \& Mabunga, 2014).

Research Instrument. The international standard questionnaire on conflict behavior survey developed by Ralph H. Kilmann \& Kenneth W. Thomas (1974) and Kenneth W. Thomas \& Ralph H. Kilmann (2017), entitled Conflict Mode Instrument, was used in this research. The survey consists of several pairs of statements describing possible behavioral responses to conflict. It has 30 pairs of statements, where respondents would indicate their preferred typical behavior in a particular conflict situation (cf Kilmann \& Thomas, 1974; Rahim, 2001; Druckman, 2005; Omisore \& Abiodun, 2014; and Thomas \& Kilmann, 2017).

Data Collection Process. Purposive sampling was used to determine the respondents and each of them was required to fill out the research Consent Form prior to participating as respondents for the research. Two modes of data gathering was utilized in this research: sending official communication (thru regular mail and electronic mails) and/or invitations to the university officials from the chosen state universities/colleges; and, thru the assistance of a national organization that conducted a national conference, where participants were mostly officials of state universities and colleges across the country. Participation letter and survey questionnaires were distributed among the said conference participants (Creswell, 1998; Marshall \& 
Table 2:

Scoring Table

\begin{tabular}{lccccc}
\multicolumn{1}{c}{ Scoring Totals } & $\begin{array}{c}\mathbf{1} \\
\text { Collaborator }\end{array}$ & $\begin{array}{c}\mathbf{2} \\
\text { Compromiser }\end{array}$ & $\begin{array}{c}\mathbf{3} \\
\text { Accommodator }\end{array}$ & $\begin{array}{c}\mathbf{4} \\
\text { Controller }\end{array}$ & $\begin{array}{c}\mathbf{5} \\
\text { Avoider }\end{array}$ \\
\hline Total from items 1-5 & & & & \\
Total from items 6-16 & & & \\
Total from items 17-24 & & & \\
Total from items 25-30 & & & \\
\hline Total & & & \\
\hline
\end{tabular}

Rossman, 2006; and Harzing, Reiche \& Pudelko, 2012).

Statistical Treatment. The tabulation of the data was done through the scoring system, which involved writing the number of points assigned for each of the five responses for the 30 situations in the suitable columns on the scoring form as shown in the table 2 .

The table 2 shows the "scoring form" based on the Conflict Mode Instrument developed by Ralph H. Kilmann \& Kenneth W. Thomas (1974) and Kenneth W. Thomas \& Ralph H. Kilmann (2017). The survey form identifies 30 situations the respondents are likely to encounter in their personal and professional lives. Respondents based their answers from the two possible behavioral responses or attitudes per pair of situations. Each of the two possible behavior response has a corresponding point equivalent, which is then used in summarizing the total scores using the scoring table 2 (cf Kilmann \& Thomas, 1974; Rahim, 2001; Druckman, 2005; Marshall \& Rossman, 2006; Omisore \& Abiodun, 2014; and Thomas \& Kilmann, 2017).

The results are, then, summarized and presented to show the scores received by each of the five conflict management styles. It would also show the ranking of the five styles from highest to lowest scores.

\section{RESULTS AND DISCUSSIONS}

This section provides the presentation of results and discussion of the conflict management styles of the officials from selected the SUCs (State Universities and Colleges) in the Philippines. Data is presented, interpreted, and analysed based on Ralph H. Kilmann \& Kenneth W. Thomas (1974)'s Conflict Mode Instrument; along with J. Hall (1976)'s Conflict Management Survey: A Survey of One's Characteristic Reaction to and Handling Conflict between Himself and Others; and Kenneth W. Thomas \& Ralph H. Kilmann (2017)'s "Thomas-Kilmann Conflict Mode Instrument: Profile and Interpretive Report" (cf Kilmann \& Thomas, 1974; Hall, 1976; Rahim, 2001; Druckman, 2005; Marshall \& Rossman, 2006; Omisore \& Abiodun, 2014; and Thomas \& Kilmann, 2017).

Profile of Respondents. Table 3 shows the basic profile of 102 respondents from selected the SUCs (State Universities and Colleges) in the Philippines.

Table 3 shows the profile of respondents. It indicates that there are 34 academic institutions with 102 respondents that participated in the research. Fifty-four (54) of the respondents are male, while the remaining 48 are female. In addition, the data shows that among the respondents: 40 are Deans, while there are 26 Associate Deans and 36 Directors.

\section{Presentation and Interpretation of}

Data. Table 4 shows the result of the responses based on the summary of scores of respondents vis-à-vis Ralph H. Kilmann \& Kenneth W. Thomas (1974)'s Conflict Mode Instrument; along with J. Hall (1976)'s Conflict Management Survey: A Survey of One's Characteristic Reaction 
Table 3:

Profile of Respondents

\begin{tabular}{|c|c|c|c|c|c|c|c|}
\hline \multirow{2}{*}{$\begin{array}{l}\text { Respondents } \\
\text { by Region }\end{array}$} & \multirow{2}{*}{$\begin{array}{l}\text { Number of } \\
\text { Institutions }\end{array}$} & \multirow{2}{*}{$\begin{array}{l}\text { Number of } \\
\text { Respondents }\end{array}$} & \multicolumn{2}{|c|}{ Sex } & \multicolumn{3}{|c|}{ Administrative Positions } \\
\hline & & & Male & Female & Deans & $\begin{array}{c}\text { Associate } \\
\text { Deans }\end{array}$ & Directors \\
\hline Region 1 & 1 & 3 & 2 & 1 & 1 & 0 & 2 \\
\hline Region 2 & 3 & 9 & 4 & 5 & 4 & 2 & 3 \\
\hline Region 3 & 3 & 9 & 3 & 6 & 3 & 3 & 3 \\
\hline Region 4A \& 4B & 4 & 12 & 7 & 5 & 5 & 3 & 4 \\
\hline Region 5 & 2 & 6 & 3 & 3 & 3 & 1 & 2 \\
\hline Region 6 & 2 & 6 & 3 & 3 & 2 & 1 & 3 \\
\hline Region 7 & 2 & 6 & 3 & 3 & 3 & 2 & 1 \\
\hline Region 8 & 2 & 6 & 2 & 4 & 2 & 2 & 2 \\
\hline Region 9 & 1 & 3 & 3 & 0 & 1 & 0 & 2 \\
\hline Region 10 & 2 & 6 & 4 & 2 & 1 & 3 & 2 \\
\hline Region 11 & 2 & 6 & 3 & 3 & 3 & 2 & 1 \\
\hline Region 12 & 1 & 3 & 2 & 1 & 2 & 0 & 1 \\
\hline CARAGA & 1 & 3 & 3 & 0 & 1 & 1 & 1 \\
\hline $\begin{array}{l}\text { National Capital } \\
\text { Region }\end{array}$ & 4 & 12 & 5 & 7 & 4 & 3 & 5 \\
\hline $\begin{array}{l}\text { Autonomous } \\
\text { Region of Muslim } \\
\text { Mindanao }\end{array}$ & 2 & 6 & 4 & 2 & 2 & 2 & 2 \\
\hline $\begin{array}{l}\text { Cordillera } \\
\text { Administrative } \\
\text { Region }\end{array}$ & 2 & 6 & 3 & 3 & 3 & 1 & 2 \\
\hline Total & 34 & 102 & 54 & 48 & 40 & 26 & 36 \\
\hline
\end{tabular}

to and Handling Conflict between Himself and Others; and Kenneth W. Thomas \& Ralph H. Kilmann (2017)'s “ThomasKilmann Conflict Mode Instrument: Profile and Interpretive Report" ( $c f$ Kilmann \& Thomas, 1974; Hall, 1976; Rahim, 2001; Druckman, 2005; Marshall \& Rossman, 2006; Omisore \& Abiodun, 2014; and Thomas \& Kilmann, 2017).

It can be gleaned from table 4 that the preferred conflict management styles of the respondents, from $1^{\text {st }}$ preference to the last one, are as follows: collaborator, compromiser, accommodator, controller, and avoider. According to Ralph H. Kilmann \& Kenneth W. Thomas (1974); J. Hall (1976); and Kenneth W. Thomas \& Ralph H. Kilmann (2017), it is both assertive and cooperative. Collaborating involves an attempt to work with the other person to find some solution that fully satisfies the concerns of both persons. It means digging into an issue to identify the underlying concerns of the two individuals and to find an alternative that meets both sets of concerns. Collaborating between two persons might take the form of exploring a disagreement to learn from each other's insights, concluding to resolve some condition that would otherwise have them competing for resources, or confronting and trying to find a creative solution to an interpersonal problem (Kilmann \& Thomas, 1974; Hall, 1976; and Thomas \& Kilmann, 2017).

The next highest conflict management style of the respondents is that of a compromiser with a score of 27 out of 102 , or $26.47 \%$. A compromiser is intermediate in both assertiveness and cooperativeness, and the object is to find some expedient, mutually acceptable solution that 
Table 4:

Summary of Results

\begin{tabular}{lcccccc}
\hline & $\begin{array}{c}\mathbf{1} \\
\text { Collaborator }\end{array}$ & $\begin{array}{c}\mathbf{2} \\
\text { Compromiser }\end{array}$ & $\begin{array}{c}\mathbf{3} \\
\text { Accommodator }\end{array}$ & $\begin{array}{c}\mathbf{4} \\
\text { Controller }\end{array}$ & $\begin{array}{c}\mathbf{5} \\
\text { Avoider }\end{array}$ & Total \\
\hline Summary of Results & 32 & 27 & 18 & 15 & 10 & 102 \\
\hline Percentage & $\mathbf{3 1 . 3 7 \%}$ & $\mathbf{2 6 . 4 7 \%}$ & $\mathbf{1 7 . 6 5 \%}$ & $\mathbf{1 4 . 7 0 \%}$ & $\mathbf{9 . 8 \%}$ & $\mathbf{1 0 0 \%}$ \\
\hline
\end{tabular}

Table 5:

Summary of Results Based on Sex of Respondents

\begin{tabular}{lcccccc} 
& $\begin{array}{c}\mathbf{1} \\
\text { Collaborator }\end{array}$ & $\begin{array}{c}\mathbf{2} \\
\text { Compromiser }\end{array}$ & $\begin{array}{c}\mathbf{3} \\
\text { Accommodator }\end{array}$ & $\begin{array}{c}\mathbf{4} \\
\text { Controller }\end{array}$ & $\begin{array}{c}\mathbf{5} \\
\text { Avoider }\end{array}$ & Total \\
\hline Male & 17 & 14 & 9 & 8 & 6 & 54 \\
Female & 15 & 13 & 9 & 7 & 4 & 48 \\
\hline Total & $\mathbf{3 2}$ & $\mathbf{2 7}$ & $\mathbf{1 8}$ & $\mathbf{1 5}$ & $\mathbf{1 0}$ & $\mathbf{1 0 2}$ \\
\hline
\end{tabular}

partially satisfies both parties. It falls on a middle ground between competing an accommodating. Compromising gives up more than competing, but less than accommodating. Likewise, it addresses an issue more directly than avoiding, but doesn't explore it in as much depth as collaborating. Compromising might mean splitting the difference, exchanging concessions, or seeking a quick middleground position (Kilmann \& Thomas, 1974; Hall, 1976; and Thomas \& Kilmann, 2017).

Following the compromiser is that of accommodator. An accommodator is considered to be unassertive and cooperative - the opposite of competing or controlling. When accommodating, an individual neglects his or her own concerns to satisfy the concerns of the other person; there is an element of self-sacrifice in this mode. Accommodating might take the form of selfless generosity or charity, obeying another person's order when one would prefer not to, or yielding to another's point (Kilmann \& Thomas, 1974; Hall, 1976; and Thomas \& Kilmann, 2017).

Controller as a conflict management style received the fourth highest rating from the respondents as can be gleaned from table 4. A controller is both assertive and uncooperative - an individual pursues his or her own concerns at the other person's expense; and this is a power-oriented mode, in which one uses whatever power seems appropriate to win one's own position one's ability to argue, one's rank, economic sanctions. Competing might mean "standing up for your rights", defending a position which you believe is correct, or simply trying to win (Kilmann \& Thomas, 1974; Hall, 1976; and Thomas \& Kilmann, 2017).

Receiving the lowest score among the conflict management style is that of an avoider. An avoider is unassertive and uncooperative - the individual does not immediately pursue his/her own concerns, or those of the other person. He or she does not address the conflict. Avoiding might take the form of diplomatically sidestepping an issue, postponing an issue until a better time, or simply withdrawing from a threatening situation (Kilmann \& Thomas, 1974; Hall, 1976; and Thomas \& Kilmann, 2017).

Table 5 shows the summary of results based on the sex of respondents. It can be inferred that there seems to be no significant difference between the responses in terms of the number of male and female respondents in every conflict management style.

Table 6 shows the distribution of responses from the Deans, Associate Deans, and Directors vis-à-vis the five conflict 
Table 6:

Summary of Results Based on the Responses of Deans, Associate Deans, and Directors

\begin{tabular}{lcccccc}
\hline & $\begin{array}{c}\mathbf{1} \\
\text { Collaborator }\end{array}$ & $\begin{array}{c}\mathbf{2} \\
\text { Compromiser }\end{array}$ & $\begin{array}{c}\mathbf{3} \\
\text { Accommodator }\end{array}$ & $\begin{array}{c}\mathbf{4} \\
\text { Controller }\end{array}$ & $\begin{array}{c}\mathbf{5} \\
\text { Avoider }\end{array}$ & Total \\
\hline Deans & 14 & 10 & 8 & 8 & 0 & 40 \\
Associate Deans & 12 & 7 & 2 & 2 & 3 & 26 \\
Directors & 6 & 10 & 8 & 5 & 7 & 36 \\
\hline Total & $\mathbf{3 2}$ & $\mathbf{2 7}$ & $\mathbf{1 8}$ & $\mathbf{1 5}$ & $\mathbf{1 0}$ & $\mathbf{1 0 2}$ \\
\hline
\end{tabular}

management styles.

It can be inferred from table 6 that the group of Deans has the most number of respondents, who chose collaborator as their number one (1) conflict management style as opposed to the groups of Associate Deans and Directors. The number of Deans and Directors, who have preferred compromiser and accommodator is the same, with 10 and 8 respondents, respectively. Furthermore, the data shows that Deans are more open to use controlling as conflict management style as opposed to Associate Deans and Directors, although the choice for controller is only fourth among the five styles. It is interesting to note though that the most number of respondents, who have chosen avoider as a conflict management style, go to the Directors (7 out of 10), followed by Associate Deans (3 out of 10), while none for Deans ( 0 out of 10).

Analysis. The above cited results are consistent with the perspective on conflict management styles commonly used by individuals in resolving inter-personal conflicts as posited by J. Blake \& S. Mouton (1970); Ralph H. Kilmann \& Kenneth W. Thomas (1974); J. Hall (1976); W.R. Pace (1983); J.G. Cragan \& D.W. Wright (1986); and Kenneth W. Thomas \& Ralph H. Kilmann (2017). This is presented in the illustration of figure 2 .

The illustration of figure 2 shows that a collaborator has both high goal orientation as well as high relationship orientation. It can be inferred, then, that the respondents of this research may have considered both concerns for their personal goals along with their relationships as important factors in resolving inter-personal conflicts. It can likewise be inferred that the respondents are both assertive and cooperative in dealing with conflicts (Fisher \& Ury, 1981; Schwarz, 2002; and Thomas \& Kilmann, 2017).

On the other hand, the respondents have chosen "avoidance" as the last resort in addressing conflicts. This is a manifestation that the respondents would want to resolve the conflicts rather than avoiding such. The respondents, then, do not want to choose being unassertive and uncooperative in addressing conflicts. However, it is important to note that those who chose to use avoidance as an option in dealing with conflicts may have considered it as a form of diplomatically sidestepping an issue, postponing an issue until a better time, or simply withdrawing from a threatening situation (cf Zhang, Harwood \& Hummert, 2005; Mabunga \& Mabunga, 2014; and Thomas \& Kilmann, 2017).

Compromising yielded the second highest score, mean and percentage among the respondents which means that they may have taken into consideration the importance of a negotiated goal and relationship orientation. It may imply that the respondents are both giving emphasis on assertiveness and cooperativeness in dealing with conflicts that is, finding some expedient, mutually acceptable solution which partially satisfies both parties.

Likewise, the respondents may have wanted to address an issue more directly than 


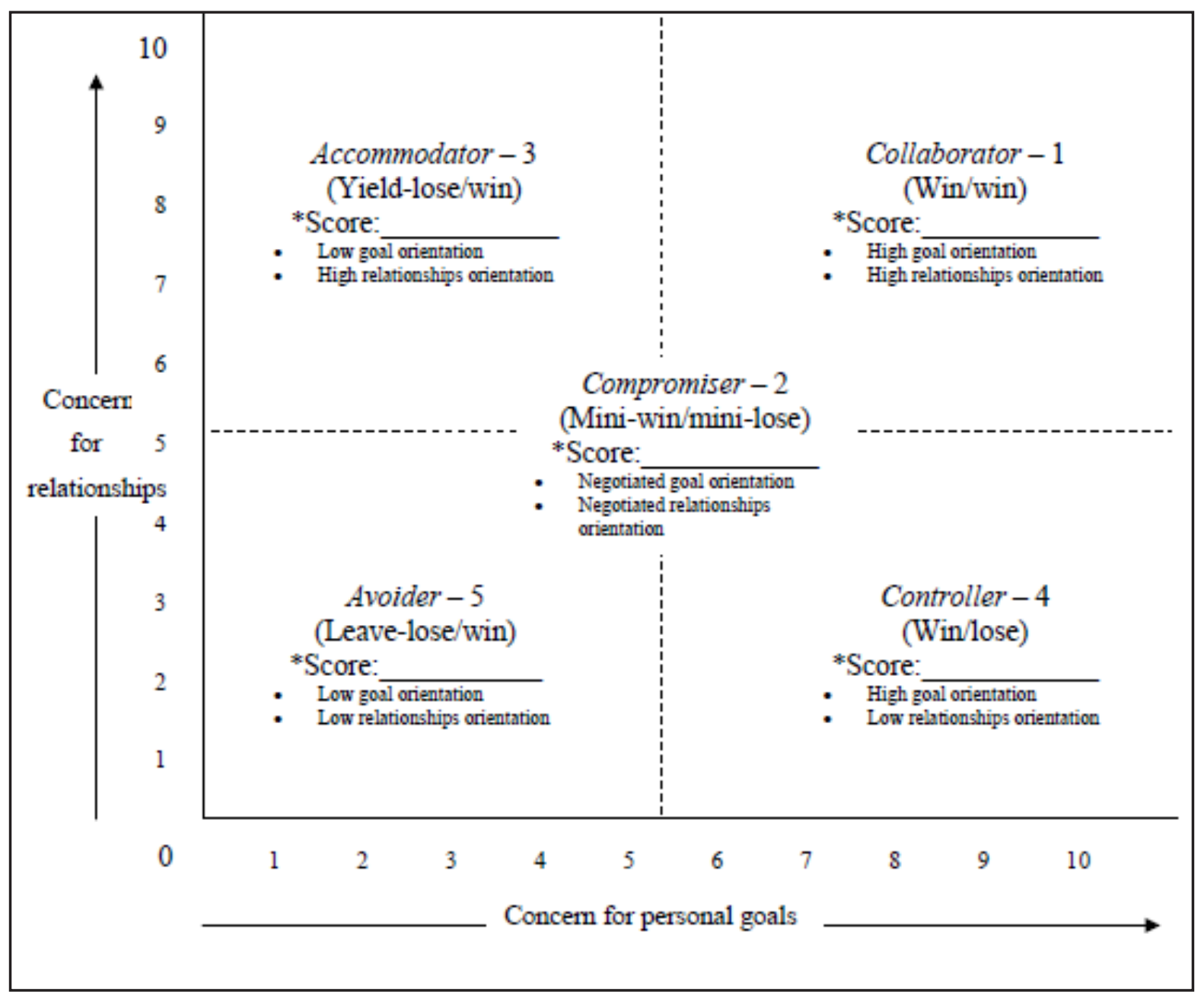

Figure 2:

The Interrelationship between and among the Conflict Management Styles

avoiding, but does not really wanted to explore it in as much depth as collaborating (Winslade \& Monk, 2001; Zhang, Harwood \& Hummert, 2005; Mabunga \& Mabunga, 2014; and Thomas \& Kilmann, 2017).

Significantly, the respondents have chosen accommodating as their third conflict management style. This suggests that they have considered more of their concerns for relationships rather than personal goals. In the same vein, it can be inferred that the respondents have considered being unassertive but cooperative in dealing with conflicts. They are likewise willing to neglect their own concerns to satisfy the concerns of others since accommodating might also takes the form of selfless generosity or charity, obeying another person's order when one would prefer not to, or yielding to another's point (Zhang, Harwood \& Hummert, 2005; Mabunga \& Mabunga, 2014; and Thomas \& Kilmann, 2017).

Controlling received the fourth option of the respondents as a means of addressing conflicts. It can be said that the respondents would have a high goal orientation, while having a low relationship orientation. It is interesting to note that the respondents have considered this conflict style which is both assertive and uncooperative, where an individual pursues his or her own concerns at the other person's expense. This is a power-oriented mode, in which one uses 
whatever power seems appropriate to win one's own position - one's ability to argue, one's rank, economic sanctions. It is likewise possible that the respondents opted for controlling as a means of "standing up for their rights", defending a position that they believe is correct, or simply trying to win (Winslade \& Monk, 2001; Zhang, Harwood \& Hummert, 2005; Mabunga \& Mabunga, 2014; and Thomas \& Kilmann, 2017).

In summary, it can be surmised that the respondents are considering addressing interpersonal conflicts with the use of not just one conflict management style. Rather, the respondents are open to the combination of the five styles presented in this research depending on the nature of the conflict situation they may get into. This is evidenced by the results indicating that there is a significant number of respondents, who have chosen all conflict management styles in resolving interpersonal conflicts (Moore, 2003; Zhang, Harwood \& Hummert, 2005; Mabunga \& Mabunga, 2014; and Thomas \& Kilmann, 2017).

In the same vein, the respondents are open to the use of the various ADR (Alternative Dispute Resolution) approaches, such as those of the poweroriented approach or controlling; rightsbased approach or controlling, collaborating, and avoiding; and interests-based approach or collaborating, compromising, accommodating, and avoiding (Augsburger, 1992; Moore, 2003; Zhang, Harwood \& Hummert, 2005; Mabunga \& Mabunga, 2014; and Thomas \& Kilmann, 2017).

\section{CONCLUSION}

The main purpose of this study is to determine the conflict management style of officials of selected the SUCs (State Universities and Colleges) in the Philippines. Based on the foregoing results and discussions, the following conclusions answering the research questions can be drawn. The dominant conflict management style officials from the selected SUCs in the Philippines is that of "collaborator". The respondents open to other conflict management styles in responding to conflicts. These styles include: compromiser, accommodator, controller, and avoider.

In addition, it can be concluded that sex and administrative positions of the respondents (university officials) do not have any statistical significant difference in their preference of conflict management styles as revealed in this study.

Given the foregoing conclusions, the following recommendations are offered as follows:

Firstly, SUCs may need to develop a conflict management system that would consider the possibility of taking into consideration the various conflict management styles that officials are using in resolving interpersonal conflicts as revealed in this study.

Secondly, while this research did not focus on determining the kind and nature of conflicts that university officials encounter at school, it is recommended that future research should consider doing a correlation between such conflicts and the conflict management styles as presented in this study.

Thirdly, a research examining how officials from private higher education institutions can likewise be conducted and have it compared with that of the public higher education institutions.

Fourthly, on an international level, a comparative study looking at the conflict management styles of selected higher education institutions officials from the ASEAN (Association of South East Asian Nations) can also be conducted as a fitting response to the ASEAN Integration phenomenon. ${ }^{1}$

\footnotetext{
${ }^{1}$ Statement: We, hereby, expressly state that this article is indeed the original work of us, which never be published or reviewed by other publishers. The content
} 


\section{References}

Alfredson, T. \& A. Cungu. (2008). Negotiation Theory and Practice: A Review of the Literature. Rome, Italy: Food and Agriculture Organization of the United Nations. Available online also at: http://www.fao.org/docs/up/ easypol/555/4-5 negotiation background paper 179en.pdf [accessed in Manila, the Philippines: January 15, 2019].

Anderson, Ian \& David Hipgrave. (2015). Philippines Political Economy Assessment Report: An Assessment of the Political Economy Factors that Shape the Prioritisation and Allocation of Resources for Essential Health Services for Women and Children. Manila: The UNICEF Office. Available online also at: https:// www.unicef.org/health/files/Philippines_PEA design version 28May15.pdf [accessed in Manila, the Philippines: January 8, 2019].

Augsburger, D. (1992). Conflict Mediation Across Cultures. Louisville, KY: John Know Press.

Avruch, K. (1998). Culture and Conflict Resolution. Washington, D.C.: USIP Press.

Becker, Gay. (2003). "Cultural Expressions of Bodily Awareness among Chronically III Filipino Americans" in Annals of Family Medicine, Volume 1(2), July, pp.113-118. Available online also at: https://www.ncbi.nlm.nih.gov/pmc/ articles/PMC1466576/ [accessed in Manila, the Philippines: January 15, 2019].

Blake, J. \& S. Mouton. (1970). "Reactions to Intergroup Completion Under Win-Lose Conditions" in Journal of Management Science, Volume 7(4), pp.420-435.

Breslin, J.S. \& J.Z. Rubin [eds]. (1993). Negotiation: Theory and Practice. Cambridge, MA: Program on Negotiation Books.

Brett, J.M. (1984). "Managing Organizational Conflict" in Journal of Professional Psychology: Research and Practice, Volume 15, pp.664-678.

Browaeys, M.J. \& R. Price. (2015). Understanding Cross-Cultural Management. New York: Pearson.

Bush, R.A.B. \& J. Folger. (2005). The Promise of Mediation: The Transformative Approach to Conflict. San Francisco, CA: John Wiley \& Sons, Inc.

CHED [Comission on Higher Education]. (2015). "Roadmap for Public Higher Education Reform". Available online at: http://www.ched.gov.ph/

and the citation in this article quoted from other authors already assigned to the respective of authors in the journals. This article is based on the fact or data obtained from the research conducted by the authors. Lastly, the authors stated that this work is far away from plagiarism.
wpcontent/uploads/Roadmap-for-Public-HigherEducation-Reform1.pdf [accessed in Manila, the Philippines: January 8, 2019].

Chikere, Cornell C. \& Jude Nwoka. (2015). "The Systems Theory of Management in Modern Day Organizations: A Study of Aldgate Congress Resort Limited Port Harcourt" in International Journal of Scientific and Research Publications, Volume 5, Issue 9 [September]. Available online also at: http://www.ijsrp.org/research-paper-0915/ ijsrp-p4554.pdf [accessed in Manila, the Philippines: January 8, 2019].

Coates, M.L., G.T. Furlong \& B.M. Downie. (2013). Conflict Management and Dispute Resolution Systems in Canadian Nonunionized Organizations. Canada: Industrial Relations Centre, first published in 1997.

Conbere, J. (2001). "Theory Building for Conflict Management System Design" in Conflict Resolution Quarterly, Volume 19(2), pp.215-236.

Constantino, R. (1994). The Philippines: A Continuing Past. Quezon City: Foundation for Nationalist Studies.

Cooper, C. et al. (1993). "Values and Communication of Chinese, Filipino, Mexican, and Vietnamese American Adolescents with Their Families and Friends" in S. Shulman \& W.A. Collins [eds]. Father-Adolescent Relationships. San Francisco: Jossey-Bass Publishers.

Costantino, C. \& C. Merchant. (1996). Designing Conflict Management Systems: A Guide to Creating Productive and Healthy Organizations. San Francisco: Jossey-Bass.

Cragan, J.G. \& D.W. Wright. (1986). Communication in Small Group Discussions. St. Paul, Minnesota: West Publishing Co.

Creswell, J.W. (1998). Qualitative Inquiry and Research Design: Choosing among the Five Traditions. Thousand Oaks, CA: Sage Publications, Inc.

De Dreu, Carsten K.W. \& Michele J. Gelfand. (2008). The Psychology of Conflict and Conflict Management in Organizations. New York and London: Taylor \& Francis Group. Available online also at: http://www.untag-smd.ac.id/ files/Perpustakaan_Digital_1/CONFLICT\%20 MANAGEMENT [accessed in Manila, the Philippines: January 8, 2019].

De Janasz, S.C., K.O. Dowd \& B.Z. Schneider. (2006). Interpersonal Skills in Organization. New York: McGraw-Hill/Irwin, $2^{\text {nd }}$ edition.

Denhardt, Robert B. \& Thomas J. Catlaw. (2015). Theories of Public Organization. Australia: Cengage Learning, seventh edition.

Denzin, N.K. \& Y.S. Lincoln. (2003). The Landscape of Qualitative Research: Theories and Issues. 
Thousand Oaks, CA: Sage Publications, Inc.

Druckman, D. (2005). Doing Research: Methods of Inquiry for Conflict Analysis. Thousand Oaks, CA: Sage Publications, Inc.

Durban, J. \& R. Catalan. (2012). "Issues and Concerns of Philippine Education through the Years" in Asian Journal of Social Sciences \& Humanities, Vol.1, No.2 [May].

Fisher, N. (2010). "A Better Way to Manage Conflict" in Political Quarterly, Volume 81(3), pp.428-430.

Fisher, L. \& W. Ury. (1981). Getting to Yes: Negotiating Agreement without Giving in. New York: Penguin Books.

Fouseki, K. (2009). "Conflict Resolution in the Management of In-Situ Museums". Paper for the $22^{\text {nd }}$ Annual International Association of Conflict Management Conference in Kyoto, Japan, on 15-18 June. Available online also at: https://papers.ssrn.com/sol3/papers. cfm?abstract id=1484888 [accessed in Manila, the Philippines: January 15, 2019].

Galace, J. \& L. Castro. (2010). Peace Education: A Pathway to a Culture of Peace. Quezon City: Center for Peace Education, Miriam College.

Gebregiorgs, M.T. (2018). "The Role of Public Interest Litigation in the Achievement of Sustainable Waste Management in Ethiopia" in Sustainability, Volume 10, pp.1-20. DOI: 10.3390/su10124735.

Geertz, Clifford. (1993). The Interpretation of Cultures: Selected Essays. London: Fontana Press, first published in 1973.

Germann, Major Wade A. (2012). "Negotiation in the Operatioal Environment". Unpublished Monograph. Fort Leavenworth, Kansas: School of Advanced Military Studies, United States Army Command and General Staff College. Available online also at: https://apps.dtic.mil/dtic/ tr/fulltext/u2/a569996.pdf [accessed in Manila, the Philippines: January 15, 2019].

Goehre, Sarah L. (2016). "Cross-Cultural Leadership in the Financial Industry: The Impact of Globalization on Corporate Culture and Leadership Effectiveness in Multinational Banks". Unpublished Bachelor Thesis. Goethe, Germany: Faculty of Economics and Business Administration, University Frankfurt. Available online also at: http://www.wiwi-frankfurt.de/ DkA/02-04-Sarah L Goehre-web.pdf [accessed in Manila, the Philippines: January 15, 2019].

Greenhalgh, Paul. (1996). "Behaviour: Roles, Responsibilties, and Referrals in the Shadow of the Code of Practice" in Wiley Online Library, on February. Available online also at: https://onlinelibrary.wiley.com/doi/ abs/10.1111/j.1467-9604.1996.tb00044.x [accessed in Manila, the Philippines: January 8, 2019].

Gutmann, H.M. (2009). "The Role of Leaders in Conflict Management" in Leader to Leader Journal, Volume 31, pp.48-53.

Haddad, Wadi D. (1995). Education Policy-Planning Process: An Applied Framework. Paris: UNESCO International Institute for Educational Planning. Available online also at: http://www.unesco.org/ education/pdf/11 200.pdf [accessed in Manila, the Philippines: January 8, 2019].

Harzing, A.W., S. Reiche \& M. Pudelko. (2012). "Challenges in International Survey Research: A Review with Illustrations and Suggested Solutions for Best Practice" in European Journal of International Management. Available online also at: https://harzing.com/ download/intres.pdf [accessed in Manila, the Philippines: January 15, 2019].

Hall, J. (1976). Conflict Management Survey: A Survey of One's Characteristic Reaction to and Handling Conflict between Himself and Others. The Woodlands, Texas: Telemetrics International, firstly published in 1969.

Hartwick, Jon \& Henri Barki. (2002). "Conceptualizing the Construct of Interpersonal Conflict" in Ecole des Hautes Etudes Commerciales de Montreal. Available online also at: http://expertise.hec.ca/gresi/wp-content/ uploads/2013/02/cahier0204.pdf [accessed in Manila, the Philippines: January 8, 2019].

HBES [Harvard Business Essentials Series]. (2003). Negotiation. Boston, MA: Harvard Business School Press.

Illes, Eva. (2001). "The Definition of Context and its Implications for Language Teaching”. Unpublished Ph.D. Thesis. UK [United of Kingdom]: Institute of Education, University of London. Available online also at: http:// discovery.ucl.ac.uk/10018870/7/Illes $\% 2 \mathrm{C} \% 20$ Eva_Redacted.pdf [accessed in Manila, the Philippines: January 15, 2019].

Irwin, David. (2001). Effective Business Communications. New York: Thorogood Publishing.

Jannat, Umma Khatuna. (2007). "Recuirement Elicitation: Identifying the Conflict between Requirement Analyst and Client". Available online at: https://www.academia.edu/9960169/ Requirement Elicitation Identifying the Conflict_between_Requirement_Analyst_and Client [accessed in Manila, the Philippines: January 8, 2019].

Jarboe, S.C. \& H.R. Witteman. (1996). “Intragroup Conflict Management in Task-Oriented Groups: The Influence of Problem Sources and Problem 
Analysis" in Small Group Research, Volume 27, pp.316-338.

Jeong, Ho-Won. (2008). Understanding Conflict and Conflict Analysis. London: SAGE Publications, Ltd. Available online also at: https://is.muni.cz/ el/1423/podzim2015/MVZ208/um/59326109/ Ho-Won Jeong_Understanding_Conflict and Conflict_Analysis_2008.pdf [accessed in Manila, the Philippines: January 8, 2019].

Jocano, F.L. (1999). Management by Culture. Manila: Punlad.

Katz, N.H. \& J.W. Lawyer. (1992). Communication and Conflict Resolution Skills. USA [United States of America]: Kendall/Hunt Publishing Company.

Kilmann, Ralph H. \& Kenneth W. Thomas. (1974). Conflict Mode Instrument. South Africa: Community Publishing Programme.

Kinicki, A. \& R. Kreitner. (2008). Organizational Behavior: Key Concepts, Skills \& Best Practices. New York: The McGraw-Hill Companies.

Lang, M. (2009). "Conflict Management: A Gap in Business Education Curricula" in Journal of Education for Business, Volume 84(4), pp.240-245.

Langlois, R.N. (1982). Systems Theory: Knowledge and the Social Sciences. New York: SUNY [State University of New York] Press.

Lewicki, R.J., B. Barry \& D.M. Saunders. (2007). Negotiation: Readings, Exercises, and Cases. New York: McGraw-Hill/Irwin, $5^{\text {th }}$ edition.

Lewins, R. (2001). "Consensus Building and Natural Resource Management: A Review" in CEMARE Research Paper, No.157, pp.1-47.

Lorena, Nicole A. \& Abelardo M. Torio. (2017). "The Road to Free Education" in The Guidon Website, on March. Available online also at: www. theguidon.com/1112/main $/ 2017 / 05 / \mathrm{road}-$ freeeducation [accessed in Manila, the Philippines: January 8, 2019].

Luhmann, N. (1995). Social Systems. Stanford, CA: Stanford University Press.

Lynch, J. (1998). “CCRA: Contemporary Conflict Resolution Approaches in J. Conbere Theory Building for Conflict Management System Design" in Conflict Resolution Quarterly, Volume 19(2), pp.215-236.

Mabunga, R.A.S. \& M.E.M. Mabunga. (2014). "Conflict Management Styles of College Students at the Philippine Normal University" in The Normal Lights: Journal of Teacher Education, Volume 8(2), pp.113-133.

Malolos, Cecilia F. \& Tereso S. Tullao, Jr. (2018). "Role of the Commission on Higher Education in Promoting Quality Education" in Working Paper Series, No.01-046, pp.1-22.

Marshall, C. \& G.B. Rossman. (2006). Designing
Qualitative Research. Thousand Oaks, CA: Sage Publications, Inc., $4^{\text {th }}$ edition.

Millett, Bruce. (1998). "Understanding Organizations: The Dominance of Systems Theory" in International Journal of Organisational Behaviour, Volume 1(1), pp.112. Available online also at: https://www. researchgate.net/publication/228691593 Understanding_organisations the dominance of systems theory [accessed in Manila, the Philippines: January 8, 2019].

Moore, C.W. (2003). The Mediation Process: Practical Strategies for Resolving Conflict. San Francisco, CA: John Wiley \& Sons, Inc.

Morillo, H.M., J.J. Capuno \& A.M. Mendoza, Jr. (2013). "Views and Values on Family among Filipinos: An Empirical Exploration" in Asian Journal of Social Sciences, Volume 41, pp.5-28. Available online also at: https://www.academia. edu/24257256/Views and Values on Family among_Filipinos_An_Empirical_Exploration [accessed in Manila, the Philippines: January 15, 2019].

NEDA [National Economic and Development Authority]. (2014). Philippine Development Plan, 2011-2016: Midterm Update. Pasig City: National Economic and Development Authority. Available online also at: http://www.neda.gov.ph/ wp-content/uploads/2014/08/NEDA-PDP-20112016-Midterm-Update+Errata2.pdf [accessed in Manila, the Philippines: January 8, 2019].

Noussia, Kyriaki. (2010). "The History, Importance, and Modern Use of Arbitration" in Confidentiality in International Commercial Arbitration. Berlin, Heidelberg: Springer, pp.11-17.

Omisore, B.O. \& A.R. Abiodun. (2014). "Organizational Conflicts: Causes, Effects, and Remedies" in International Journal of Academic Research in Economics and Management Sciences, Vol.3, No.6 [November]. Available online also at: http://hrmars.com/hrmars_papers/ Organizational_Conflicts_Causes,_Effects and Remedies.pdf [accessed in Manila, the Philippines: January 15, 2019].

Orbeta Jr., Aniceto C., Kathrina G. Gonzales \& Sol Francesca S. Cortes. (2016). "Are Higher Education Institutions Responsive to Changes in the Labor Market?" in PIDS Discussion Paper Series, No.08. Available online also at: https:// pidswebs.pids.gov.ph/CDN/PUBLICATIONS/ pidsdps 1608 rev.pdf [accessed in Manila, the Philippines: January 8, 2019].

Overton, A.R. \& A.C. Lowry. (2013). “Conflict Management: Difficult Conversations with Difficult People" in Clinics in Colon and Rectal Surgey, Volume 26(4), December, pp.259-264. 
Available online also at: https://www.ncbi.nlm. nih.gov/pmc/articles/PMC3835442/ [accessed in Manila, the Philippines: January 15, 2019].

Pace, W.R. (1983). Organizational Communication. New Jersey: Prentice Hall.

Pauwels, Luc. (2012). “A Multimodal Framework for Analyzing Websites as Cultural Expressions" in Journal of Computer-Mediated Communication, Volume 17, Issue 3, 1 April 2012, Pages 247-265. Available online also at: https://academic.oup. com/jcmc/article/17/3/247/4067660 [accessed in Manila, the Philippines: January 15, 2019].

Pfetch, F. (2007). Negotiating Political Conflicts. New York: Palgrave Macmillan.

Proszowska, A. (2015). "The Impact of the Exhibitor's Cultural Context on the Use of Forms of Communication in the Management Process of the Exhibitor's Participation in Fairs" in Jagiellonian Journal of Management, Volume 2, pp.119-130.

Putnam, L.L. \& M.S. Poole. (1987). “Conflict and Negotiation" in F.M. Jablin et al. [eds]. Handbook of Organizational Communication: An Interdisciplinary Perspective. Newbury Park, CA: Sage, pp.549-599.

Rahim, M. Afzalur. (2001). Managing Conflict in Organizations. London: Quorum Books, $3^{\text {rd }}$ edition. Available online also at: http://www. untag-smd.ac.id/files/Perpustakaan_Digital 1/ CONFLICT\%20MANAGEMENT [accessed in Manila, the Philippines: January 15, 2019].

Raiffa, Howard. (2002). "Contributions of Applied Systems Analysis to International Negotiation" in Victor A. Kremenyuk [ed]. International Negotiation: Analysis, Approaches, Issues. San Francisco, CA: Jossey-Bass,. $2^{\text {nd }}$ edition.

Roloff, M.E. (1987). The Handbook of Communication Science. Newbury Park, CA: SAGE Publication.

Rowe, M. (1997). "Dispute Resolution in Non-Union Environment in J. Conbere Theory Building for Conflict Management System Design" in Conflict Resolution Quarterly, Volume 19(2), pp.215-236.

Santiago III, Eugenio Ferrer. (2018). "Corruption Prevention in State Colleges and Universities" in KnE Social Sciences: ${ }^{\text {th }}$ International Research Conference on Higher Education, pp.446-468. Available online also at: https:// knepublishing.com/index.php/Kne-Social/ article/view/2398/5274 [accessed in Manila, the Philippines: January 8, 2019].

Schwarz, R.M. (2002). The Skilled Facilitator. San Francisco: Jossey-Bass.

Scott, W. Richard \& Gerald F. Davis. (2016). Organizations and Organizing: Rational, Natural, and Open System Perspectives. London and New
York: Routledge, Taylor \& Francis Group, first published 2007.

Silverman, D. (1971). The Theory of Organizations. New York: Basic Books.

Slaikeu, K. \& R. Hasson. (2001). "Controlling the Costs of Conflict in J. Conbere Theory Building for Conflict Management System Design" in Conflict Resolution Quarterly, Volume 19(2), pp.215-236.

Sparks, Dennis. (2007). Leading for Results: Transforming Teaching, Learning, and Relationships in Schools. Thousand Oaks, California: A Sage Publications Company, second edition.

Spaho, K. (2013). “Organizational Communication and Conflict Management" in Management, Vol.18(1), pp.103-118.

Spencer-Oatey, H. (2012). "What is Culture? A Compilation of Quotations" in Global PAD Core Concepts. Available online also at: https:// warwick.ac.uk/fac/soc/al/globalpad/openhouse/ interculturalskills/global pad _ - what is culture. pdf [accessed in Manila, the Philippines: January 15, 2019].

SPIDR [Society of Professionals in Dispute Resolution]. (1999). Report on Competencies in Conflict Management Systems Design. Washington, DC: Association for Conflict Resolution.

Stipanowich, T.J. \& J.R. Lamare. (2012). "Living with ADR: Evolving Perceptions and Use of Mediation, Arbitration, and Conflict Management in Fortune 1,000 Corporations" in Fortune 1,000 Survey TJS Revised, on February 19. Available online also at: https://www.mdcourts.gov/ sites/default/files/import/macro/pdfs/reports/ cornellstudy2013.pdf [accessed in Manila, the Philippines: January 15, 2019].

Thakore, Digvijaysinh. (2013). "Conflict and Conflict Management" in IOSR Journal of Business and Management (IOSR-JBM), Volume 8, Issue 6 [March - April], pp.07-16. Available online also at: http://www.iosrjournals.org/iosr-jbm/papers/ Vol8-issue6/B0860716.pdf?id=5165 [accessed in Manila, the Philippines: January 8, 2019].

Thomas, Kenneth W. \& Ralph H. Kilmann. (2017). "Thomas-Kilmann Conflict Mode Instrument: Profile and Interpretive Report". A Report prepared for PAT Sample, on April 7, pp.1-11.

Toh, S.H. \& V. Cawagas. (1987). Peace Education: A Framework for the Philippines. Quezon City, Philippines: Phoenix Publishing House, Inc.

Ury, W.L., J.M. Brett \& S. Goldberg. (1993). Getting Disputes Resolved: Designing Systems to Cut the Costs of Conflict. Cambridge, Mass: The Program on Negotiation at Harvard Law School.

Wealleans, David. (2017). The Organizational 
Measurement Manual. New York: Routledge.

Winslade, J. \& G. Monk. (2001). Narrative Mediation: A New Approach to Conflict Resolution. San Francisco, CA: John Wiley \& Sons, Inc.

Wurtz, Elizabeth. (2006). "Intercultural Communication on Web sites: A Cross $\square$ Cultural Analysis of Web sites from High $\square$ Context Cultures and Low $\square$ Context Cultures" in Journal of Computer-Mediated Communication, Issue of August. Available online also at: https://onlinelibrary.wiley.com/doi/ full/10.1111/j.1083-6101.2006.tb00313.x [accessed in Manila, the Philippines: January 15, 2019].

Yirik, S., B.I. Yildirim \& N. Cetinkaya. (2015). “A Study on Conflict Management and Conflict
Resolution in Hospitality Organizations" in International Journal of Arts \& Sciences, Volume 08(08), pp.77-88. Available online also at: http://universitypublications.net/ijas/0808/ pdf/F5N134.pdf [accessed in Manila, the Philippines: January 15, 2019].

Zhang, Y.B., J. Harwood \& M.L. Hummert. (2005). "Perceptions of Conflict Management Styles in Chinese Intergenerational Dyads" in Communication Monographs, Volume 72(1), March. Available online also at: $\underline{\text { htps:// }}$ www.researchgate.net/publication/47453477 Perceptions_of_Conflict_Management_Styles in Chinese Intergenerational Dyads [accessed in Manila, the Philippines: January 22, 2019]. 
RONALD ALLAN S. MABUNGA \& MARIA ELJIE M. MABUNGA,

Conflict Management among Selected Officials of State Universities and Colleges

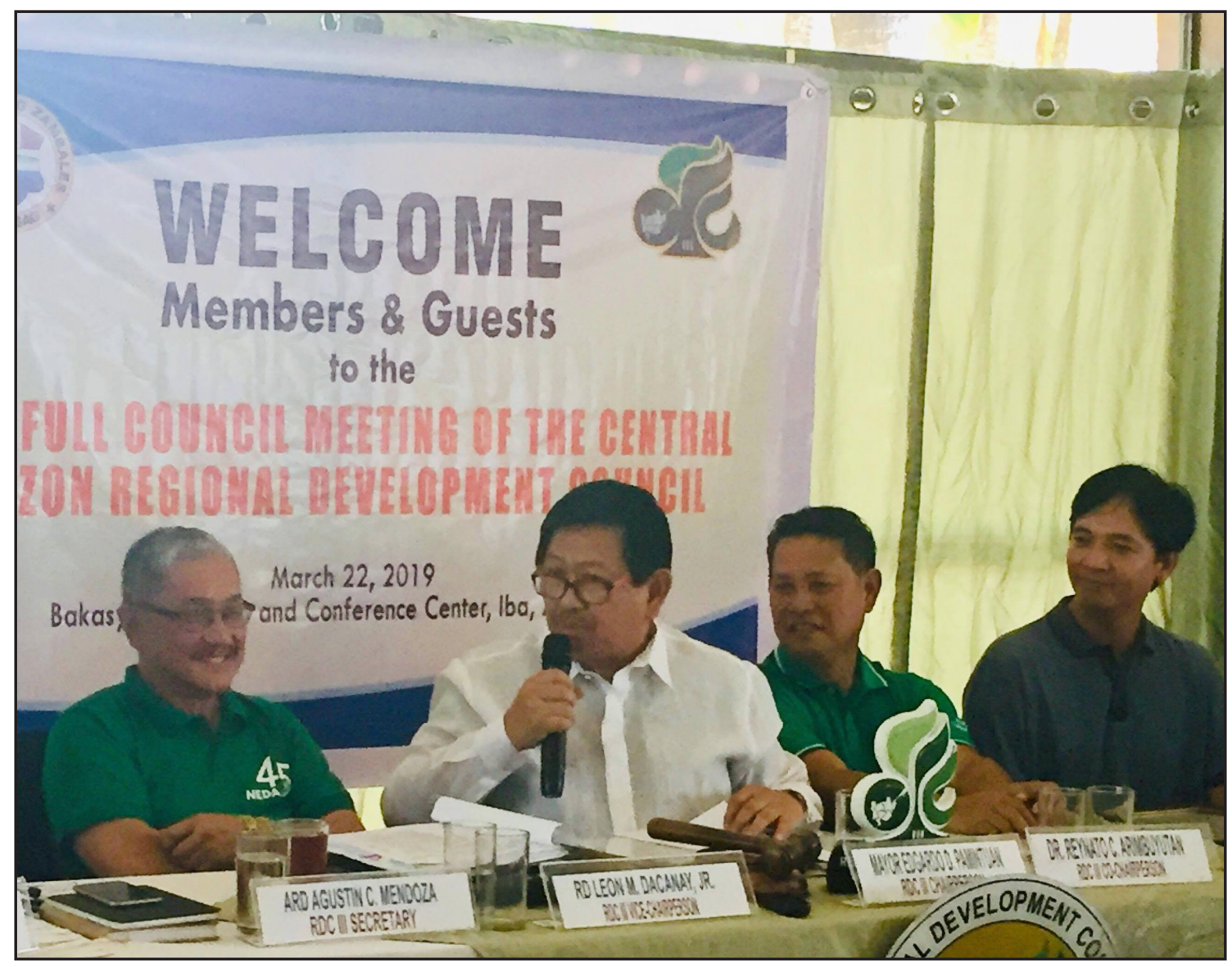

The Officials of SUCs in the Philippines

(Source: https://pia.gov.ph/news, 30/3/2019)

The dominant conflict management style officials from the selected SUCs (State Universities and Colleges) in the Philippines is that of "collaborator". The respondents open to other conflict management styles in responding to conflicts. These styles include: compromiser, accommodator, controller, and avoider. In addition, it can be concluded that sex and administrative positions of the respondents (university officials) do not have any statistical significant difference in their preference of conflict management styles as revealed in this study. 